\title{
Chatbot for COVID-19 Emergency Response and Digital Neighborhood Surveillance
}

\author{
Ayu Amalia ${ }^{1, *}$ Mohammad Sani Suprayogi ${ }^{2}$ \\ ${ }^{1}$ Communication Dept. Universitas Muhammadiyah Yogyakarta, Yogyakarta, Indonesia \\ ${ }^{2}$ Engineering Dept, GDILab, Jakarta, Indonesia \\ *Email: ami.khavid@umy.ac.id
}

\begin{abstract}
COVID-19 pandemic gradually leads to habits shifting amongst Indonesians, which indirectly alters the increase of internet usage by $40 \%$ during 'Work from Home' period instigated by the Government (CNN Indonesia, 2020). Social media access is claimed as the main reason why netizens connect to the internet, indicated by $19,1 \%$ of 171.17 million internet users in Indonesia (Association of Indonesia Internet Service Provider (APJII) 2019). Social media's 'reach' is considered as the indicator of the expansion and distribution of information potentials, marked by the production, dissemination and exertion of information by social media users or the netizens. Thus, highlights potential of independent neighborhood surveillance conducted progressively and continuously by social media users (netizens) to respond COVID-19 emergency matter through microblog-based social media platform known as 'Twitter'. This research described Twitter chatbot feature potentials in order to respond netizens' needs for information related to COVID-19 in Central Java province, as well as revealed Twitter's chatbot practicality as a feature to accommodate government practice and policy implementation on digital neighborhood surveillance program during COVID-19 emergency respond instigated by Central Java Provincial Government.
\end{abstract}

Keywords: Twitter, Chatbot, COVID-19, Neighborhood Surveillance, Central Java

\section{INTRODUCTION}

Corona Virus Disease-19 (Covid-19) outbreak is an unexpected virologic disaster, forcing people to adapt with various ways to prevent the risk of transmission. As the Indonesian government, they urge people to work, study and worship from home since March 2020 [1]. Government instigation indirectly impacts on the increase of public internet access through personal digital devices, considering that Corona virus, which is also known as Covid-19, is a relatively new virologic disaster which drives people to take advantage from the internet, accessing an online news portal that provides information about Covid-19. It is triggered by the people curiosity about a variety of information concerning Covid-19, ranging from clinical indications, treatment methods, and environmental observations that allow residents of an area to know the number of people diagnosed with Covid-19 in their surrounding. Public curiosity about Covid-19 pandemic

has led to the increase of total visits to several online news portals, as was the case with visits to Detik.com,
Tribunnews.com, Kompas.com, Liputan6.com, and Suara.com [2], as indicated by the following figure.

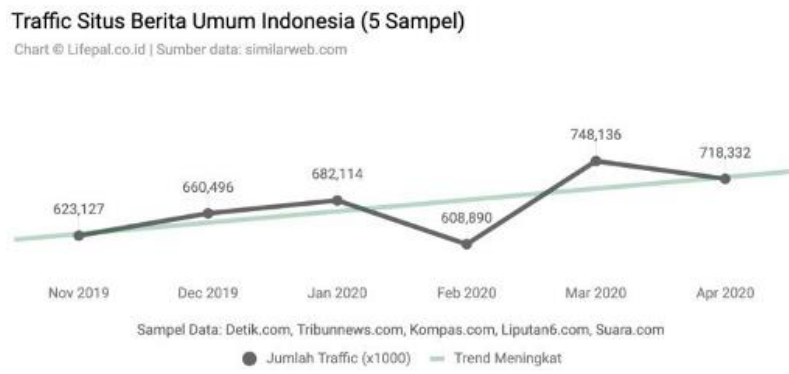

Fig. 1. The traffic of news website during pandemic lockdown in Indonesia

Indications of the increasing visits on online news portals have been detected since January 2020. Although experienced a decline in February 2020, the number rose up in March 2020 since the President officially urged people to study, work, and worship from home; and commit to social distancing [1]. Covid-19 as information that captured public attention initiated several online 
news portals that have contributed to the development of this issue by configuring Covid-19 statistical dashboard regularly updated both on a national and regional scale. Mainstream online news portals such as Kompas, CNN Indonesia, Detik and Liputan6 post Covid-19 statistical dashboards to their respective web pages. Covid-19 is the most popular keyword on search engines connected to the internet [2].

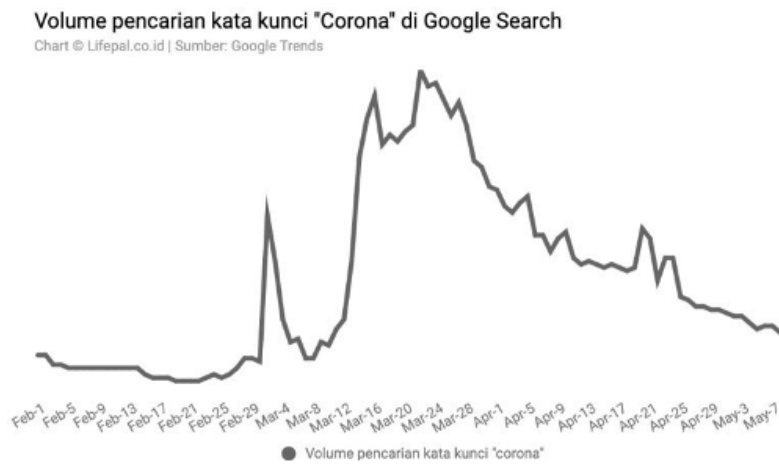

Fig. 2. 'Search' volume using 'Corona' keyword on Google

Study shows that the search for Covid-19 information by internet users does not only use the keywords 'Corona', 'Corona Virus', or 'Covid-19', but also by using the words telling the symptoms that are relevant to the disease such as detected loss of smell (anosmia), as it was partially reported by New York Times in April 2020, that at least $30 \%$ of Covid-19 patients complained of anosmia. It is in line with the results of a study reported by University College London researchers which stated that searches for Covid-19 information based on keyword symptoms were carried out by internet users massively, not only in the US, but also in Canada, England, Australia, France, Italy and Greece [3]. Such particular approach to comprehend data across the internet known as 'big data', though big data is considered sufficiently less rewarding especially in regards with misinformation and hoaxes, it is able to provide advantages related to data and information management as 'big datal' was precepted as "very large sets of data that are produced by people using the internet, and that can only by stored, understood, and used with the help pf special tools and methods."

This research reflected the previous study that implemented chatbot to build human-like interaction on social media, titled 'Engaging Millennials on Using Chatbot Messenger for Eco-Tourism' [4], that described the use of social media chatbot implemented on direct message feature on Twitter to provide information in an interactive manner for its users as well as to reveal social media (Twitter) chatbot potential as auto-responder that helps Millennial tourists to gain comprehension on EcoTourism as they embark on their travels, effectuating Eco-Tourism practice.
Based on the previous study, this research was set in to explore social media chatbot potential on messenger platforms, i.e. Twitter direct message (DM), to assist its users undertaking neighborhood surveillance digitally during Covid-19 pandemic, specifically Twitter chatbot that was developed by Central Java Covid-19 Task Force on Central Java Provincial Government official Twitter account @ provjateng (https://twitter.com/provjateng).

\subsection{Chatbot as smart conversational agent in the vastness of 'big data'}

Chatbot enables interactive communication between users and platforms which requires digital platforms to provide non-static content demanding user's appropriate knowledge and ability to curate specific information. Social media users are encouraged to be able to harness social media as a reliable reference in user-generatedcontent era, which is initiated in Web 2.0 era, in terms of enabling internet users with any kinds of background, including the non- capable one, to be able to perform as a 'gatekeeper' since digital platforms undermine series of processes to filter, select and curate information provided by the internet. It enables users to switch roles from information recipients to individual or collective 'gatekeeper'. Web 2.0 presence is suspected to have a negative effect regarding authorities of the 'gatekeeping' process through the 'portal' reduction process (gate) which has an impact on decreasing accountability and skills in managing information [5]. The information system built regarding this research allows users to perform 'gatekeeping' process more dynamically with the help of chatbots which work as auto-responders, functioned as information aggregators, and are needed by messenger users to commit neighborhood surveillance task through digital devices such as smartphones using digital platform or social media known as Twitter.

Chatbot is a form of human-computer dialog system that is operated through natural language via text or speech [6]. In general, chatbot on messenger platform indicates the automation process carried out by the platform developers or platform programmers to facilitate interactions that occur between platforms and users. Chatbot as well as other technology products come with impacts. Beneficially, chatbot reduces information availability cycle significantly. On the other hand, information obtained using chatbot technology must be able to answer reliability, validity and neutrality issues as well as media content in general. Information provided with chatbot assistance at the same time is challenged with 'independence' matters. It also corresponds with "does information delivered by chatbot, is value-free of even immune from certain interests?". It indicates that chatbot can also be used as an effective digital campaign tool [7]. The idea of chatbot implementation is initiated from the policy decisions system provided by social media platforms which later pertain to automation. It 
means that chatbot programs have many commercial implementations and are often known as virtual assistants or assisting conversational agents [8].

Commercial use of chatbot, especially as part of a digital device, flared in 2016, "By all accounts, 2016 is the year of the chatbot". Chatbot is a digital entity on language technology advancement, recognized as intelligent virtual assistant, and well known with several terms such as digital assistants, conversational interface or simply 'chatbot'. It is used widely and known as Apple's Siri, Microsoft's Cortana, Amazon's Alexa, and Google's New Assistant which are operated based on voice-command, and other forms of chatbots for specific functionalities for messaging platforms which are operated by text-command [9].

Chatbot uniqueness stands as a form of auto-response feature, namely a programmable digital entity. Chatbot is assigned to derive data from internet at large, that includes data from social media, websites, and generic digital databases such as text, numeric, image, audio, video that go through digitalization process and accessible via internet, associated with big data. Commencing from those notions, big data is perceived as data collected from internet users in general that tends to be organic, considering that internet serves various functions of different levels of users.

\subsection{Digitalization of public information as a mean of neighborhood surveillance for Covid-19 pandemic}

Covid-19 pandemic has driven changes on public routines, which indirectly impacts on the increase of internet usage by $40 \%$ during 'Work from Home' period in Indonesia [10]. The increase in the volume of internet usage is not only due to the changes in the context of scope for work, and conducting academic activities for students, it is also contributed by availability of the latest information about Covid-19 on digital platforms such as social media.

Big data management during the emergency response period for Covid-19 pandemic refers to social media usage as a form of highly-used new media among netizens, as claimed by the Indonesian Internet Service Providers Association (APJII) for the internet user behavior and internet penetration survey in 2018, which stated that social media become the most accessed digital platform on the internet as it had $19.1 \%$ of the 171.17 million internet users in Indonesia [11]. Social media users are generally familiar with various social media formats (platforms), both video and photo sharing based, such as Instagram, Pinterest, YouTube, social networksbased such as Facebook, and microblogging social media, such as Twitter. Twitter's daily users in Indonesia have experienced a significant increase, from 134 million to 166 million in 2019 , as stated by Twitter's CEO, Jack Dorsey [12].

Global Twitter developer, on March 24, 2020 launched the 'Event Page' feature to provide Twitter users with official and reliable information related to the Covid-19 pandemic in real time which refers to information released by government agencies/officials, the public, and the media [13]. Twitter developers in Indonesia are aware of the potential for neighborhood surveillance and initially activates \#coronavirus hashtag which promote information from authorized agencies, such as the Indonesian Ministry of Health (@KemenkesRI), Ministry of Communication and Informatics. RI (@kemkominfo).

\section{IMPLEMENTATION}

This study was conducted by observing the use of chatbot developed for Twitter direct message (DM), specifically on Central Java Provincial Government official Twitter account@provjateng

(https://twitter.com/provjateng). Twitter was selected amongst various social media with a consideration that Central Java Provincial Government has already set several Twitter accounts for public service purpose, including: first, @LaporGub_ (\#LaporGub) which is used to accommodate public reports in regard to public facilitates or governmental service for public across Central Java province via web and android based reporting system, and second, @KemalaJateng (\#KemalaJateng) which is a channel to address public reports toward specific Governmental authorized agency directly, in order to mitigate bureaucratic stage, especially for Covid-19 outbreak emergency response.

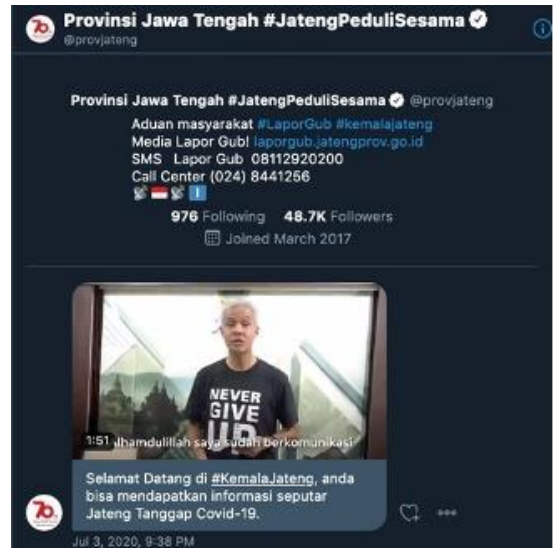

Fig. 3. @provjateng Twitter account's direct message feature homepage

Responding Covid-19 outbreak, @ provjateng Twitter chatbot was developed as a part of the Integrated Command Post for the Prevention and Handling of the Covid-19 pandemic in Central Java Province (Posko Terpadu Pencegahan dan Penanganan Pandemi Covid-19 Prov. Jawa Tengah). Central Java Governor, Ganjar Pranowo, is involved in the integrated campaign for the 
Covid-19 pandemic countermeasures by providing recommendations to the public through instructional video embedded on direct message feature, as shown in figure 3 .

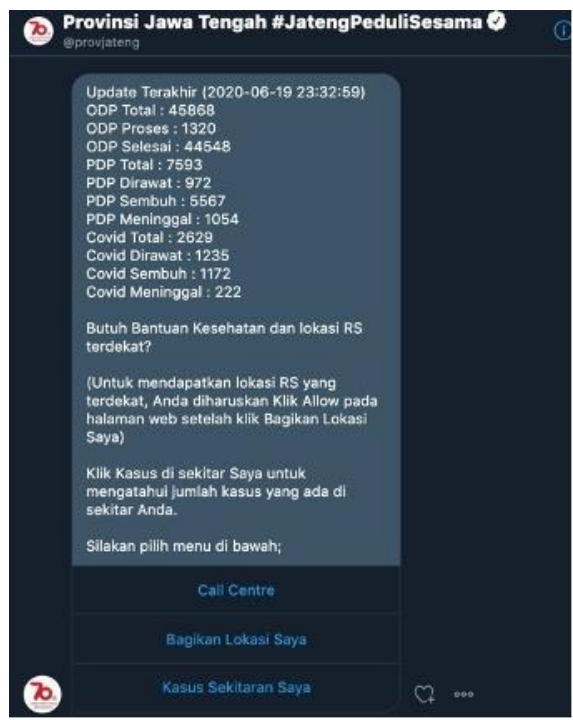

Fig. 4. Statistical data display and main menu for @provjateng's Twitter Direct Message

Government obligations to promote transparency to the public is implemented in the next phase for this particular direct message feature, as shown in figure 4. Data from the last update are displayed in a statistical manner, managed centrally by placing the Center for Public Health (Pusat Kesehatan Masyarakat/Puskesmas) as the smallest unit of data collection related to Covid-19 pandemic. The hierarchically integrated data collection process leads to the Central Java Provincial Health Office (Dinas Kesehatan Provinsi Jawa Tengah). Furthermore, the collected data is processed digitally to be displayed on http://corona.jatengprov.go.id website (as seen in figure 5), which is synchronized in parallel with @ provjateng Twitter direct message.

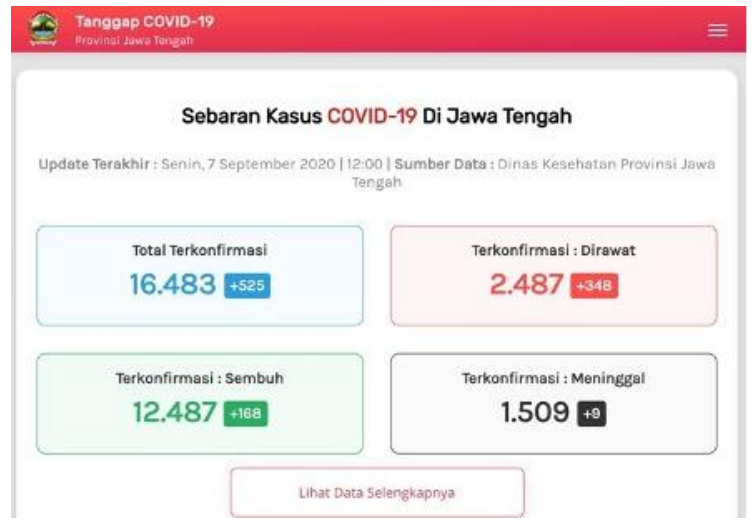

Fig. 5. Updated Covid-19 data on http://corona.jatengprov.go.id
Frequently updated data displayed on the main menu of @ provjateng direct message feature (as shown by figure 4) highlights extra menu to provide Twitter users with information that would require their contribution to voluntarily report their wellbeing and also their surroundings by activating their location access or Geotag from their digital devices. In return, they will receive information for the nearest medical facility, at the same time, detects Covid-19 cases prevails surrounds their neighborhood. This process involves social media users, government or the authorities, and social media developers to collaborate and conduct neighborhood surveillance, preserve their surroundings, and prevent the massive spread of Covid-19.

@provjateng's Twitter interactive direct message feature also enables the users to obtain on-demand information resembling communication with active entities and form interactive communication known as programmable interactivity, due to chatbot, which is operated as part of the direct message feature. Twitter users are able to sort one of interactive direct message menu (DM Menu) to gain updated information regarding Covid-19, as seen in figure 6 .

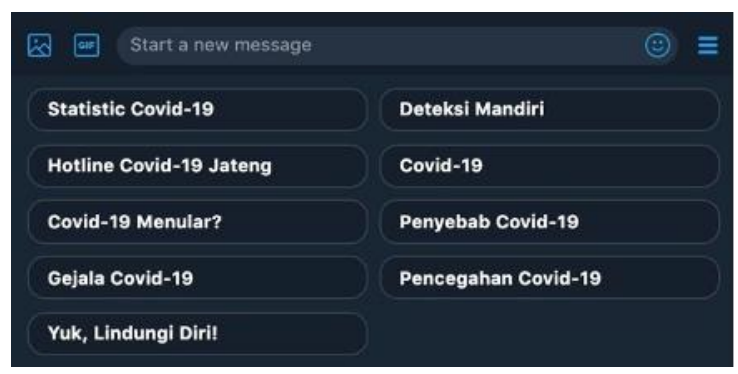

Fig. 6. DM menu as tool for interactive communication with Chatbot

\section{DISCUSSION}

Chatbot as part of the Twitter direct message services performs multiple functions both as an autoresponder, and as digital entity that connects several services such as navigation service known as Location Based Services (LBS) appointed nearest medical facilities to manage medical response related to Covid-19 case, and at the same time detects indwelling location for Covid-19 patients in order to map the spread of Covid-19 cases more widely.

Social media fundamentally provides coverage and reach of information to a (specific) public as the target of the information dissemination. Social media allows a decentralized distribution of information, but at the same time has a network of its own, with millions of users at various intersections for information production and consumption [14].

The indicator information distribution by social media is characterized by 'reach', which includes the flow 
of information, as information is produced, consumed, and distributed by social media users themselves. This has the potential for independent, progressive and sustainable neighborhood surveillance carried out by social media users as part of society, recognized as EWOM, through social media as the staple.

Covid-19 pandemic is designated by the Government as a national disaster with the signing of Presidential Decree No. 12 of 2020 concerning 'Establishment of the Non- Natural Disaster Covid-19 Outbreak as a National Disaster' ('Penetapan Bencana Nonalam Penyebaran Covid-19 sebagai Bencana Nasional') on April 13, 2020. The emergency response was followed up by Central Java Governor, Ganjar Pranowo, as initiated on April 2, 2020 through the official Twitter account of the Central Java Provincial Government (@ provjateng) by assigning \#BersamaLawanCorona hashtag, which was followed by the chatbot feature addition, equipping@provjateng's Twitter direct message (DM) service.

The chatbot feature (Chatter Bot) is formed as an autoresponder feature similar to information center, or hotline, and FAQ (Frequently Asked Questions) page on websites, or manual books, which generally provides information related to certain issues. Research dentified chatbot as an intelligence agent which interacts via conversations, using text or audio [15], specifically, Twitter chatbot (Twitter bot) functioned to respond to non- programmatic (random) input. As in 2007, Twitter chatbot was used to respond online conversations [16].

Chatbot operates similarly with instant messaging, by replicating interaction patterns among humans on machine learning which allows computers to learn natural language processing without programming process [17]. Machine learning is a branch of artificial intelligence (A.I.) which functions as programming machines with cutting-edge software (intelligence software), identical to artificial intelligence entities in general, machine learning is operated based on algorithms with data supply from big data, specifically related relevant science (study), by applying the Knowledge Discovery from Data (KDD) method, data mining methods, and pattern recognition. [18]. Machine learning is a process that drives services (platforms) utilized by many internet users, where machine learning provides a recommendation system, as offered by streaming platforms such as Netflix, YouTube, Spotify; search engine platforms such as Google and Baidu; social-media feeds such as on Facebook and Twitter; voice assistants such as Siri and Alexa [19]. Chatbot identify the questions (input) users by matching patterns, access to information in the database, based on the information entered to provide a pre- programmed response (predefined information) [20].

Social media has potential to be operated as the primary medium or advocating media, responding to emergency, as social media spreads warning and information to the public, parallel with to government regulations. Obligatory, Governments or the authorities need to conduct series of assessments in order to be able to respond to the needs of society in accordance with technological developments and with regard to existing emergencies.

\section{CONCLUSION AND RECOMMENDATIONS}

Big data2 is precepted as "is high-volume, highvelocity and/or high-variety information asset that demands cost- effective, innovative forms of information processing that enable enhanced insight, decision making, and process automation.". The progressive use of big data could assist to simplify bureaucracy and procedural (rules), especially with regard to the emergencies that require strategic decision making in a minimum time due to automation and efficiency. Big data could act as system that allows people to send out data, and allows digital platform developer to gain and analyze data in such systematic and structured manner using social network analysis to determine information distribution patterns along digital platform streamline, or to be applied as supporting feature to activate relevant services such as location-based-service (LBS) to determined location or area as observational object or object relating to emergencies.

Taking advantage of the synergy between social media and big data, the Government can progressively respond to the needs of fast-paced society, one of them, replacing a number of public information center with responsive digital features are that accessible for public, such as social media's chatbot as it serves numerous functions: (1) Social media (messenger) chatbot allows users to gain personalized user experience, and improve quality of chatbot and user interactions (interactivity); (2) Social media chatbot has the ability to function as a digital campaign instrument to support a more elaborate emergency response program; (3) Social media chatbot is able to perform as an information aggregator which provides users with comprehensive information by automatically synchronizing multi platforms, such as Location Based Service (LBS) to detect Covid-19 patients whereabouts and at the same time, providing them with the nearest medical facility available; (4) Chatbot has the potential to organize conversations, and is operated as questionnaire complimentary tool, generating users' information, collected as a database which is beneficial for extensive research or further campaign.

Disaster emergency response requires a comprehensive contribution involving government agencies, media, and public in a progressive and continuous manner. Covid-19 pandemic has become a defining period for the implementation of bureaucratic efficiency by displaying public information based on real 
and actual data, as well as involving citizens to utilize affordable technology such as social media facilitated by the chatbot feature.

Public information digitalization as an alternative for the production and distribution of information is considered as public's right. It predominantly aims to reduce or eliminate series of misunderstandings initiated by misinformation or hoaxes, to facilitate public, to actively contribute for the sake of neighborhood surveillance. As neighborhood surveillance is conducted based on the accumulated data by the government that would be accessible for public to minimize the potential for the spread of disaster and mitigate disaster impact while responding the Covid-19 pandemic.

\section{ACKNOWLEDGMENT}

Special acknowledgment is dedicated to Central Java Provincial Government and Twitter Kemala Jateng (https://twitter.com/provjateng).

\section{REFERENCES}

[1] D. Prastiwi, "Imbauan Jokowi terkait Covid-19, dari Kerja dari Rumah hingga Ingatkan Social Distancing - News Liputan6.com,” 2020. https://www.liputan6.com/news/read/4202629/imb auan- jokowi-terkait-covid-19-dari-kerja-darirumah-hingga- ingatkan-social-distancing (accessed Sep. 09, 2020).

[2] R. Mulyawan, "Inilah Data Efek Covid-19 Pada Traffic Situs Berita, Pekerjaan, Belanja, Kesehatan, dan Travel | Technologue," 2020. https://technologue.id/inilah-data- efek-covid-19pada-traffic-situs-berita-pekerjaan-belanjakesehatan-dan-travel/amp/ (accessed Sep. 09, 2020).

[3] A. Zaenudin, "Mendeteksi Penyebaran Corona Melalui Kata Kunci di Google - Tirto.ID,” 2020. https://tirto.id/mendeteksi-penyebaran-coronamelalui- kata-kunci-di-google-eLSS (accessed Sep. 09, 2020).

[4] A. Amalia and M. Suprayogi, "Engaging Millennials on Using Chatbot Messenger for EcoTourism," 2019.

[5] L. Chin-Fook and H. Simmonds, "Redefining gatekeeping theory for a digital generation," McMaster J. Commun., vol. 8, no. 1, pp. 7-34, 2011.

[6] R. Gorwa and D. Guilbeault, "Unpacking the Social Media Bot: A Typology to Guide Research and Policy," Policy \& Internet, Aug. 2018, doi: 10.1002/poi3.184.
[7] T. Gillespie, "Platforms Intervene," Soc. Media + Soc., vol. 1, no. 1, p. 205630511558047 , Apr. 2015, doi: 10.1177/2056305115580479.

[8] J.-P. Sansonnet, D. Leray, and J.-C. Martin, "Architecture of a Framework for Generic Assisting Conversational Agents," Springer, Berlin, Heidelberg, 2006, pp. 145-156.

[9] R. Dale, "The return of the chatbots," Nat. Lang. Eng., vol. 22, no. 5, pp. 811-817, 2016.

[10] CNN Indonesia, "Pengguna Internet Kala WFH Corona Meningkat 40 Persen di RI," 2020. https://www.cnnindonesia.com/teknologi/2020040 812494 7-213-491594/pengguna-internet-kala-wfhcorona- meningkat-40-persen-di-ri (accessed Sep. 09, 2020).

[11] APJII, "Penetrasi dan Perilaku Pengguna Internet Indonesia 2018," $\quad$ APJII, 2019. https://apjii.or.id/survei (accessed May 29, 2019).

[12] A. S. Jati, "Jumlah Pengguna Twitter Meningkat, Tapi..." https://inet.detik.com/cyberlife/d5001786/jumlah- pengguna-twitter-meningkat-tapi (accessed Sep. 09, 2020).

[13] A. Yudhawiranata, "Peluncuran fitur 'Event page' Covid- 19 di Indonesia." https://blog.twitter.com/in_id/topics/company/2020 /Pelun curan-Event-page-Covid19-diIndonesia.html (accessed Sep. 09, 2020).

[14] D. M. Boyd and N. B. Ellison, "Social network sites: Definition, history, and scholarship," J. Comput. Commun., vol. 13, no. 1, pp. 210-230, 2007.

[15] X. Sánchez-Díaz, G. Ayala-Bastidas, P. FonsecaOrtiz, and L. Garrido, "A knowledge-based methodology for building a conversational chatbot as an intelligent tutor," in Mexican International Conference on Artificial Intelligence, 2018, pp. 165-175.

[16] M. Tsvetkova, R. García-Gavilanes, L. Floridi, and T. Yasseri, "Even good bots fight: The case of Wikipedia,” PLoS One, vol. 12, no. 2, p. e0171774, 2017.

[17] G. Jindal, D. Upadhyay, and A. Jha, "Whatsapp Chatbot," EasyChair, 2020.

[18] M. Mohammed, M. B. Khan, and E. B. M. Bashier, Machine learning: algorithms and applications. Crc Press, 2016.

[19] K. Hao, "What is machine learning? | MIT Technology "Review." https://www.technologyreview.com/2018/11/17/10 3781/what-is-machine-learning-we-drew-youanother- flowchart/ (accessed Sep. 29, 2020).

[20] M. Dahiya, "A tool of conversation: Chatbot," Int J. Comput. Sci. Eng., vol. 5, no. 5, pp. 158-161, 2017. 